\title{
Durable Response to Letrozole in a Patient with Relapsed Low Grade Endometrial Stromal Sarcoma Metastatic to the Lung - A Case Report
}

\author{
Samer Salah ${ }^{1 *}$, Yacob Saleh ${ }^{1}$, Mais Zmaily ${ }^{2}$ and Omar Jaber ${ }^{3}$ \\ ${ }^{1}$ Department of Medical Oncology, King Hussein Cancer Center, Amman, Jordan \\ ${ }^{2}$ Department of Radiology, King Hussein Cancer Center, Amman, Jordan \\ ${ }^{3}$ Department of Pathology, King Hussein Cancer Center, Amman, Jordan
}

*Corresponding author: Dr. Samer Salah, Department of Medical Oncology, King Hussein Cancer Center, Amman, Jordan, Tel: +962795727966, E-mail: samer.salahmd@gmail.com

Received date: October 26, 2019; Accepted date: December 02, 2019; Published date: December 09, 2019

Citation: Salah S, Saleh Y, Zmaily M, Jaber O (2019) Durable Response to Letrozole in a Patient with Relapsed Low Grade Endometrial Stromal Sarcoma Metastatic to the Lung - A Case Report. Med Case Rep Vol.5 No.3:127.

\section{Abstract}

Low Grade Endometrial Stromal Sarcomas (LGESS) are rare uterine neoplasms, with high propensity for local recurrence and an indolent course. Distant metastasis is rare. Hormonal therapy with progestin or aromatase inhibitors has been used successfully to treat relapsed and unresectable disease. We report a 55-year-old female patient with relapsed LGESS in the lungs, who achieved almost complete response to letrozole for more than 6 years. To our knowledge, this is the longest reported durable response with letrozole in patients with LGESS and lung metastasis.

Keywords: Lung; Metastasis; Tomography; Letrozole

\section{Introduction}

Low grade endometrial stromal sarcomas (LGESS) are rare malignant neoplasms with an estimated incidence of 1-2 per million women [1]. This tumor accounts for only $0.2 \%$ of all uterine malignancies and less than $10 \%$ of uterine sarcomas [2]. Although the pathogenesis of LGESS remains uncertain, unopposed estrogen and use of Tamoxifen have been implicated [3]. Affected women are typically peri-menopausal and of younger age (median age 45-55 years) compared to patients with other uterine sarcomas [3]. LGESS has high local recurrence rates. Nevertheless, distant metastasis is rare [3].

There is an increasing evidence supporting efficacy of aromatase inhibitors for relapsed LGESS. However, efficacy data is mainly derived from case reports and small series, showing objective responses [4-7]. In the current paper we report a case of LGESS with lung metastasis, who achieved unprecedented almost complete response to letrozole that is ongoing beyond 6 years.

\section{Case Report}

A 55-year-old female patient presented with menorrhagia and was referred to our center after she had hysterectomy and right salpingo-oophorectomy in October 2010.
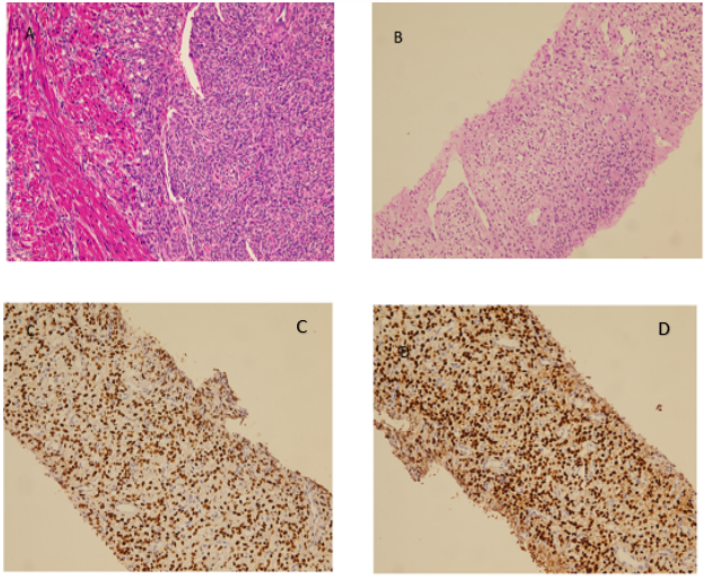

Figure 1: Pathologic diagnosis of low grade endometrial stromal sarcoma metastatic to lung: A: Low grade endometrial stromal sarcoma infiltrating the myometrium. The tumor is composed of uniform, oval to fusiform cells with scant cytoplasm. Hematoxylin and eosin, 200x. B: A core biopsy from the lung shows metastatic low grade endometrial stromal sarcoma. Notice the monomorphic, uniform population of tumor cells that morphologically resemble the tumor cells in the uterus. Hematoxylin and eosin, 200x. C: Estrogen receptor immunohistochemical stain in the metastatic low-grade endometrial sarcoma to the lung. Estrogen receptor immunohistochemical stain, 200x. D: Progesterone receptor immunohistochemical stain in the metastatic low-grade endometrial sarcoma to the lung. Progesterone receptor immunohistochemical stain, $200 x$. 
Pathology evaluation of her resected uterus revealed LGESS, which was confirmed upon review at our center (Figure 1A). Her first post-operative computed tomography (CT) scan in 3 months after surgery showed no evidence of disease.

In April 2011, a follow up CT scan of the abdomen and pelvis revealed recurrence with a mass lesion infiltrating the vagina and pathologically enlarged pelvic lymph nodes. She initiated megestrol acetate in May 2011 at a dose of 80 mg orally daily, and initially had partial response. However, in November 2012, imaging studies showed progression of the pelvic mass, the pelvic lymph nodes, and interval development of lung nodule suggestive of metastasis (Figure 2A). A CT guided lung biopsy was performed and confirmed the diagnosis of metastatic LGESS (Figures 1B-1D).
In November 2012, therapy with letrozole $2.5 \mathrm{mg}$ orally daily was initiated. Her subsequent CT scan showed partial response of the pelvis and lung metastasis. Further regression was demonstrated on subsequent scans following initiation of letrozole (Figure 2B). Follow up CT scans at more than 6 years of initiating letrozole showed almost complete remission in lung metastasis and stable pelvic soft tissue mass (Figure $\mathbf{2 C}$ ).

She was also maintained on calcium and vitamin-D supplements as preventive measures for osteoporosis. She has tolerated letrozole without any appreciable toxicities. Her treatment with letrozole is still ongoing at 78 months from the date of its initiation.
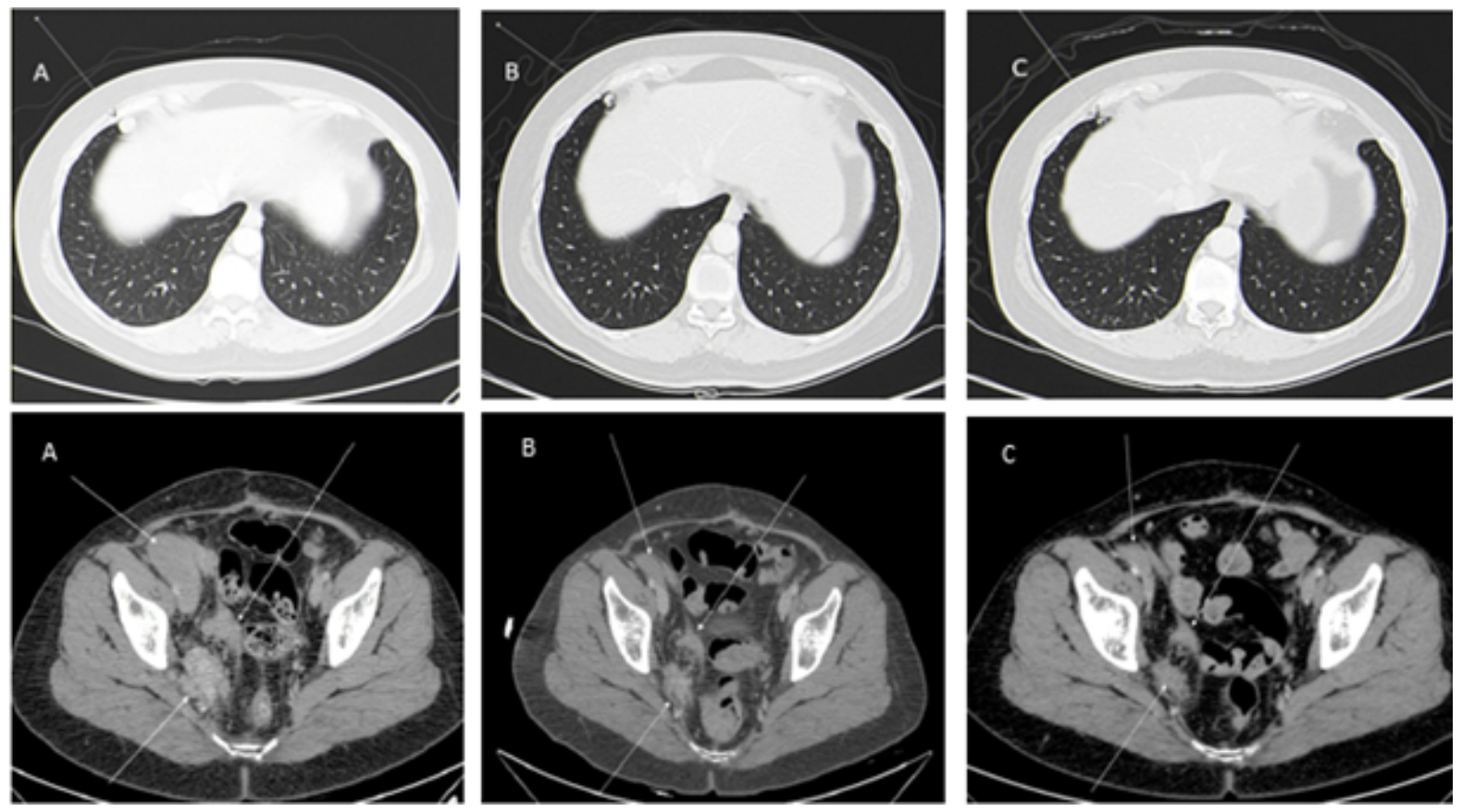

Figure 2: CT scan of chest and pelvis; (A) Before starting letrozole in November 2012 showing target lesion in right lung, pelvic mass and pelvic LNs. (B) Durable partial response in April 2014. (C) Most recent imaging showing almost complete remission in lung meets and stable pelvic mass.

\section{Discussion}

Surgical resection is the mainstay therapy for LGESS $[1,2]$. Pre-operatively, it is often difficult to differentiate LGESS from uterine leiomyoma, and the diagnosis is often made after hysterectomy. Similar to leiomyoma, LGESS usually present with abnormal uterine bleeding, pelvic mass, or abdominal pain.

Gross examination of LGESS reveals intracavitary or mural tumor masses with nodular or diffuse permeation of the uterine wall. Commonly, the tumor may be found as intravenous tumor plugs. The cut surfaces are tan-yellow, fleshy and soft. Necrosis and cystic formation can be seen but are generally not common. Histologically, the tumor is composed of monomorphic population of tumor cells arranged in sheets that infiltrate the myometrium. The tumor cells are oval in shape with scant cytoplasm that resembles the normal proliferative endometrial stroma cells.

Scattered among the tumor cells are few small arterioles with hyalinized walls, a finding characteristic for LGESS. The mitotic count is usually low. The tumor cells are typically positive for CD10, estrogen and progesterone receptors immunohistochemical stains. On the other hand, high grade endometrial stromal sarcoma is composed of undifferentiated oval to spindle cells with moderate to severe atypia and high mitotic count. The tumor cells may show expression of cyclin D1 with variable expression of estrogen and progesterone receptors immunohistochemical stains.

LGESS is often confined to the uterus at initial presentation. However, up to a third may present with disease that extends to surrounding structures such as the fallopian tubes, ovaries, and urinary bladder. Local recurrence is common after 
hysterectomy and may occur late [3-5]. Therefore, adjuvant radiation or hormonal therapy with progestins is commonly practiced although a good evidence supporting adjuvant therapy is lacking.

However, efficacy of progestins such as megesterol acetate, and aromatase inhibitors ( $\mathrm{Al}$ ) have been demonstrated for patients with unresectable advanced disease $[6,7]$. Owing to its rarity, the data showing objective responses with these agents are derived from case reports and small series, mainly with megesterol acetate and letrozole [8]. Serkies et al., in their retrospective study, identified only 5 cases treated with aromatase inhibitors from two institutions over a 10-year period, which highlights the rarity of this disease [9].
Typically, LGESS are slow growing tumors with an indolent course and a good prognosis. Patients with relapsed disease can have long term survival with repeated surgery and hormonal therapy $[1,7]$. Although most relapses are confined to pelvis and abdomen, lung metastasis is extremely rare [1]. Therefore, it is not clear if lung metastasis is associated with a more aggressive course or with durable responses to aromatase inhibitors. In the reported literature we identified a few cases with lung metastasis treated with letrozole (Table 1) [6-19].

Table 1: Summary of literature reporting the use of aromatase inhibitors in low grade endometrial stromal sarcomas.

\begin{tabular}{|c|c|c|c|c|c|c|c|}
\hline $\begin{array}{l}\text { Authorl } \\
\text { Reference }\end{array}$ & $\begin{array}{l}\text { Number } \\
\text { of } \\
\text { patients } \\
\text { treated } \\
\text { with Al }\end{array}$ & Age & Treatment & Line & Response & $\begin{array}{l}\text { Duration of } \\
\text { response/ Disease } \\
\text { control }\end{array}$ & Sites of disease \\
\hline $\begin{array}{l}\text { Yamaguchi } \\
\text { M, et al. [6] }\end{array}$ & 5 & & Letrozole & first & $\begin{array}{ll}2 \mathrm{CR}, & 1 \\
\mathrm{PR}, & 2 \\
\mathrm{SD} & \end{array}$ & +10 to $+96 \mathrm{~m}$ & Unclear \\
\hline Serkies K [8] & 5 & & $\begin{array}{l}\text { Letrozole } \quad 4, \\
\text { anastrozole } 1\end{array}$ & $\begin{array}{l}4 \text { first line } 1 \text { second } \\
\text { line (letrozole) }\end{array}$ & $\begin{array}{l}4 \mathrm{SD}, 1 \\
\mathrm{DP}\end{array}$ & $\begin{array}{l}\text { SD +133 m, SD } \\
+127 \mathrm{~m}, \mathrm{SD}+26 \mathrm{~m} \\
\mathrm{PD}, \mathrm{SD}+15 \mathrm{~m}(2 \mathrm{nd} \\
\text { line })\end{array}$ & $\begin{array}{l}\text { Abdomen and pelvic } \\
\text { recurrence }\end{array}$ \\
\hline $\begin{array}{l}\text { Nakamura K, } \\
\text { et al. [9] }\end{array}$ & 1 & & letrozole & $3 r d$ & PR & +6 years & $\begin{array}{l}\text { Para-aortic LN, lung (the lung } \\
\text { was in CR after pulmonary } \\
\text { metastasetomy before starting } \\
\text { letrozole) }\end{array}$ \\
\hline $\begin{array}{l}\text { Wolfe } H \text {, et } \\
\text { al. [10] }\end{array}$ & 1 & & $\begin{array}{l}\text { Letrozole then } \\
\text { exemestane (both } \\
\text { as adjuvant after } \\
\text { repeater surgery) }\end{array}$ & $\begin{array}{l}\text { Letrozole second } \\
\text { adjuvant after } \\
\text { megesterol acetate. } \\
\text { Exemestane 3rd } \\
\text { adjuvant }\end{array}$ & $\begin{array}{l}\text { Not } \\
\text { assessa } \\
\text { ble } \\
\text { (adjuvant } \\
\text { setting) }\end{array}$ & $\begin{array}{l}2 \text { years with adj } \\
\text { letrozole, } 5 \text { years } \\
\text { with adj exemestane }\end{array}$ & $\begin{array}{l}\text { Abd/ pelvis (resected). No } \\
\text { residual disease prior to } \\
\text { initiation of } \mathrm{Al}\end{array}$ \\
\hline & 2 & Pt 1: 51 & Pt 1: Letrozole & Pt 1: second line & Pt 1: CR & Pt 1: +80 & Pt 1: peritoneal metastasis \\
\hline $\begin{array}{l}\text { Ryu H, et al. } \\
{[7]}\end{array}$ & & Pt 2: 49 & Pt 2: Letrozole & 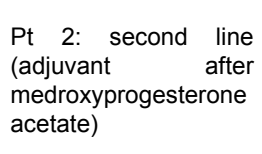 & $\begin{array}{l}\text { Pt 2: not } \\
\text { assessa } \\
\text { ble } \\
\text { (adjuvant } \\
\text { setting) }\end{array}$ & $\begin{array}{l}\text { Pt 2: no recurrence } \\
\text { at } 57 \mathrm{~m} \text { of starting } \\
\text { letrozole }\end{array}$ & $\begin{array}{l}\text { Pt 2: adjuvant after resection of } \\
\text { pelvic disease }\end{array}$ \\
\hline $\begin{array}{l}\text { Yang } \mathrm{KH} \text {, et } \\
\text { al. [11] }\end{array}$ & 1 & 50 & $\begin{array}{l}\text { Letrozole (and } \\
\text { ovarian radiation) }\end{array}$ & First line & PR & 24 & Lung metastasis \\
\hline $\begin{array}{l}\text { Sylvester VT, } \\
\text { et al. [12] }\end{array}$ & 1 & 59 & letrozole & First line & CR & 24 & Unresectable pelvic recurrence \\
\hline $\begin{array}{l}\text { Krauss K, et } \\
\text { al [13] }\end{array}$ & 1 & 36 & Letrozole & First line & PR & 39 & $\begin{array}{l}\text { Lung, soft tissue (psoas } \\
\text { muscle) and peritoneal }\end{array}$ \\
\hline $\begin{array}{l}\text { Bréchot JM, } \\
\text { et al. [14] }\end{array}$ & 1 & 56 & Letrozole & First line & $\mathrm{CR}$ & More than 2 years & Lungs \\
\hline \multirow{4}{*}{$\begin{array}{l}\text { Pink D, et al. } \\
\text { [1] }\end{array}$} & 5 & $\begin{array}{l}\text { No } \\
\text { data, } \\
55,39 \\
67,47\end{array}$ & Letrozole & Pt 1: 2nd & Pt 1: PR & Pt 1: +37 & Pt 1: lung \\
\hline & - & - & - & Pt 2: 1st & Pt 2: PR & Pt 2: +9 & Pt 2: Local recurrence \\
\hline & - & - & - & Pt 3: 1st & Pt 3: PR & Pt 3: +10 & Pt 3: Local recurrence \\
\hline & - & - & - & Pt 4: 2nd & Pt 4: PD & $\begin{array}{l}\text { Pt 4: primary } \\
\text { progressive }\end{array}$ & Pt 4: Local recurrence \\
\hline
\end{tabular}




\begin{tabular}{|c|c|c|c|c|c|c|c|}
\hline & - & - & - & Pt 5: 1st & Pt 5: PR & Pt $5:+3$ & Pt 5: Local and peritoneal \\
\hline $\begin{array}{l}\text { Leunen } M \text { et } \\
\text { al. [15] }\end{array}$ & 1 & 76 & Letrozole & First line & PR & Unclear & Unresectable pelvic recurrence \\
\hline $\begin{array}{l}\text { Maluf FC, et } \\
\text { al. [16] }\end{array}$ & 1 & 51 & Letrozole & $\begin{array}{l}\text { Second line (after } \\
\text { Megestrol acetate) }\end{array}$ & PR & 9 & $\begin{array}{l}\text { Unresectable pelvic recurrence } \\
\text { that progressed after } \\
\text { Megesterol acetate }\end{array}$ \\
\hline \multirow{3}{*}{$\begin{array}{l}\text { Dahhan } \mathrm{T} \text { et } \\
\text { al. [17] }\end{array}$} & 3 & $\begin{array}{l}38,48, \\
85\end{array}$ & Letrozole & Pt 1: 2nd-line & Pt 1: PR & $\begin{array}{l}\text { Pt 1: Not clear, but } \\
\text { follow up for } 6 \mathrm{~m}\end{array}$ & Pt 1: Pelvis + distant \\
\hline & - & - & - & Pt 2: 1st-line & Pt 2: PR & $\begin{array}{l}\text { Pt 2: not clear, but } \\
\text { follow up at } 4 \mathrm{~m}\end{array}$ & Pt 2: Distant \\
\hline & - & - & - & Pt 3: 1st-line & Pt 3: PD & $\begin{array}{l}\text { Pt 3: primary } \\
\text { progressive }\end{array}$ & Pt 3: Pelvis \\
\hline $\begin{array}{l}\text { Tzakas E, et } \\
\text { al. [18] }\end{array}$ & 1 & 48 & Letrozole & 2nd line & PR & 29 & Local + Lung \\
\hline
\end{tabular}

\section{Conclusion}

To our knowledge, the duration of response to letrozole in our patient represent the longest durable response of LGESS and lung metastasis and suggests that a durable control can be achieved with aromatase inhibitors when the disease spreads outside the abdomen and pelvis. Given the rarity of lung metastasis in LGESS, we performed a lung biopsy for our patient. In our opinion, biopsy is needed to exclude the possibility of more aggressive histologies, such as high grade undifferentiated uterine sarcomas or other primaries. In conclusion, the reported durable response to letrozole in our case suggests that long term disease control can be achieved in metastatic LGESS to lungs. To our knowledge, this is the first report of lung- metastatic LGESS that had an ongoing response to Al for more than 6 years.

\section{Conflict of Interest}

No conflict of interest to declare.

\section{References}

1. Pink D, Lindner T, Mrozek A, Kretzschmar A, Thuss-Patience PC, et al. (2006) Harm or benefit of hormonal treatment in metastatic low-grade endometrial stromal sarcoma: Single center experience with 10 cases and review of the literature. Gynecol Oncol 101: 464-469.

2. Boardman CH, Webb MJ, Jefferies JA (2000) Low-grade endometrial stromal sarcoma of the ectocervix after therapy for breast cancer. Gynecol Oncol 79: 120-123.

3. Ashraf-Ganjoei T, Behtash N, Shariat M, Mosavi A (2006) Low grade endometrial stromal sarcoma of uterine corpus, a clinicopathological and survey study in 14 cases. World J Surg Oncol 4:50.

4. Husseiny GE, Bareedy NA, Mourad WA, Mohamed G, Shoukri M, et al. (2002) Prognostic factors and treatment modalities in uterine sarcoma. Am J Clin Oncol 25: 256-260.

5. Stadsvold JL, Molpus KL, Baker JJ, Michael K, Remmenga SW (2005) Case report-Conservative management of a myxoid endometrial stromal sarcoma in a 16-year-old nulliparous woman. Gynecol Oncol 99: 243-245.
6. Yamaguchi M, Erdenebaatar C, Saito F, Motohara T, Miyahara $Y$, et al. (2015) Long-term outcome of aromatase inhibitor therapy with letrozole in patients with advanced low-grade endometrial stromal sarcoma. Int J Gynecol Cancer 25:1645-1651.

7. Ryu H, Choi YS, Song IC, Yun HJ, Jo DY, et al. (2015) Long-term treatment of residual or recurrent low-grade endometrial stromal sarcoma with aromatase inhibitors: A report of two cases and a review of the literature. Oncol Lett 10:3310-3314.

8. Serkies K, Abacjew-Chmyłko A, Wieczorek-Rutkowska M, Pęksa R (2018) Aromatase inhibitor therapy for endometrial stromal sarcoma - two-centre experience. Ginekol Pol 89:607-610.

9. Nakamura K, Nakayama K, Ishikawa M, Ishikawa N, Katagiri $\mathrm{H}$, et al. (2016) Letrozole as second-line hormonal treatment for recurrent low-grade endometrial stromal sarcoma: A case report and review of the literature. Oncol Lett 12:3856-3860.

10. Wolfe H, Bunch K, Stany M (2015) Prolonged response to exemestane following multiple surgical resections and hormonal therapies in a patient with recurrent endometrial stromal sarcoma. Gynecol Oncol Rep 15:4-6.

11. Yang KH, Shin JA, Jung JH, Jung HW, Lee HR, et al. (2015) A Case of Metastatic Low-Grade Endometrial Stromal Sarcoma Treated with Letrozole after Ovarian Ablation by Radiotherapy. Cancer Res Treat 47:958-962.

12. Sylvestre VT, Dunton CJ (2010) Treatment of recurrent endometrial stromal sarcoma with letrozole: a case report and literature review. Horm Cancer 1:112-115.

13. Krauss K, Bachmann C, Hartman JT, Siegmann K, Sotlar K, et al. (2007) Management of late recurrence of a low-grade endometrial stromal sarcoma (LGESS): Treatment with letrozole. Anticancer Res 27; 3477-3480.

14. Brechot JM, Kamboucher M, Brauner M, Destable MD, Duperron F, et al. (2007) Pulmonary metastases from endometrial stromal sarcoma may benefit from hormone therapy. Rev Mal Respir 24; 69-72.

15. Leunen $M$, Breugelmans $M$, De Sutter $P$, Bourgain $C$, Amy JJ (2004) Low-grade endometrial stromal sarcoma treated with the aromatase inhibitor letrozole. Gynecol Oncol 95:769-771.

16. Maluf FC, Sabbatini P, Schwartz L, Xia J, Aghajanian C (2001) Endometrial stromal sarcoma: objective response to letrozole. Gynecol Oncol 82:384-388. 
17. Dahhan T, Fons G, Buist M, Ten Kate FJ, Van der Velden J (2009) The efficacy of hormonal treatment for residual or recurrent low-grade endometrial stromal sarcoma. A retrospective study. Eur J Obstet Gynecol Reprod Biol 144(1): 80-84.

18. Tzakas E, Liu S, Todd RW (2009) Hormonal therapy with letrozole prior to surgical management of recurrent metastatic low-grade endometrial stromal sarcoma (LGESS). J Obstet Gynaecol Res 29(8): 778-779.

19. Jain R, Batra S, Ahmad A, Elahi AA, Gupta M, et al. (2015) Low grade endometrial stromal sarcoma: A case report. Iran J Med Sci 40:81-84 